\title{
Coping Strategies for Someone Divorced
}

\author{
Andria Pragholapati
}

\section{Definition of Coping}

Lazarus (1985) states coping is a constant cognitive and behavioral change in an effort to overcome specific internal and or external demands that are exhausting or exceeding an individual's source.

\section{Coping Strategy Definition}

Coping strategy is a method used to change the environment or situation or solve problems that are being felt / faced (Rasmun, 2004). According to Keliat (1999, in Suliswati, 2005), Coping Strategy is a way that individuals do in solving problems, adjusting to changes, and responding to threatening situations. The Coping Strategy is formed through a process of learning and remembering, which starts from the beginning of the onset of the stressor and when it starts to be realized the impact of the stressor. This ability to learn depends on external and internal conditions, so the role is not only how the environment forms the stressor but also the condition of the individual's temperament, perception, and cognition of the stressor.

According to Lazarus and Folkman (1984) Coping Strategies are cognitive and behavioral efforts that are constantly changing to manage demands from within and or from outside individuals that are perceived to be detrimental to or exceeding that individual's abilities. According to Stuart (2007), every effort is directed at managing stress, including efforts to solve problems directly and the ego defense mechanism used to protect themselves. Based on the above understanding, it can be concluded that the Coping Strategy is an individual's reaction when faced with a stress or stress and how the individual cope with the stress he is facing.

\section{Source of Coping}

Stuart (2013) mentions coping sources consisting of economic assets (material assets), abilities and talents (personal abilities), social support (social support), and positive attitudes (positive beliefs). Other coping sources are energy balance, spiritual support, positive beliefs, problem solving, social abilities, physical health, material and social resources.

A person's spiritual beliefs and positive outlooks can be intended as a basis for hope and can justify one's coping efforts in the most adverse circumstances. Problem solving abilities include the ability to search for information, identify problems, weigh a choice, and implement an action plan. Social abilities facilitate problem solving including the problems of others, increase the possibility of cooperation and support from others, and provide the greatest social control to the individual. Material assets show money, goods and services where money can buy everything. It 
is clear that financial resources greatly increase one's coping choices in almost any stressful situation (Lazarus and Folkman, 1984).

Knowledge and intelligence are other coping sources that allow people to see different ways of dealing with stress. Coping sources also include the commitment of the strength of the ego's identity to social networks, cultural balance, a stable system of values and beliefs, health and generic prevention orientation or strength of body movement (Lazarus and Folkman, 1984).

Cramer (2000) in Aldwin \& Yancura, compares similarities and differences between Coping Strategies and coping processes. Coping strategies are done unconsciously, intentionally, dispositionally, hierarchically, and related to pathology, while the coping process is done consciously, used intentionally, situationally determined, nonhierarchical, and related to normality.

\section{Types of Coping Strategies}

Coping responses can be described as positive or negative and reactive (for example reacting to one's own thoughts and feelings) or active (dealing with actual stressful situations or events). Active or reactive coping coping can be positive or negative, depending on the situation and the content of the response. There are many ways to deal with stress. Research on stress shows that people tend to use a number of different coping approaches rather than just one (Laal \& Aliramaie, 2010).

Positive coping strategies are learned techniques used by individuals to reduce tension, stress, and anxiety; for example, deep breathing techniques, and relaxation exercises. This strategy can produce successful adaptations. A person can be therapeutic and non-therapeutic. Management strategies usually help people to gain insight, gain confidence to face reality, and develop emotional maturity. Coping is an important aspect of the interface of people with the environment. The type of coping strategy used in a particular situation is a function of each personality or experience difference and the characteristics of the situation (Laal \& Aliramaie, 2010).

The Coping Strategy can be divided into two namely coping that focuses on problems and coping that focuses on emotions. An emotionally focused coping is an attempt to control emotional responses to very stressful situations. Co-ops that focus on emotions tend to be done when individuals are unable or feel unable to change stressful conditions, what individuals do is regulate their emotions. A problem-focused coping is an effort to reduce stressors, by learning new ways or skills to be used in changing situations, circumstances, or issues. individuals will tend to use this strategy if they believe they will quickly change the situation. Coping that focuses on emotions is coping that is done to ignore stressors while coping that focuses on problems emphasizes more on efforts to resolve problems completely to stop stressors (Lazarus \& Folkman, 1984).

In addition, according to Potter \& Perry (2005) there is a task-oriented Coping Strategy that is solving problems directly, and there is also an ego defense mechanism that is an indirect coping method of stress. The task-oriented coping strategy is direct problem solving techniques to deal with threats, including the use of cognitive abilities to reduce stress, solve problems, resolve 
conflicts and meet needs (Stuart \& Sunden, 1991). Task-oriented behavior empowers a person to realistically face the demands of a stressor.

The three general types of task-oriented behavior are attack behavior, withdrawal behavior and compromise behavior. Attacking behavior is the act of getting rid of or overcoming a stressor or to satisfy needs, whereas withdrawal behavior is withdrawing physically or emotionally from a stressor, and compromising behavior is changing methods that can be used, changing goals, or eliminating satisfaction with the need to meet needs or to avoid stress (Potter \& Perry, 2005).

Lazarus and Folkman (1984) identified several aspects of coping that focused on problems and coping that focused on emotions obtained from his studies. Coping aspects that focus on emotions are seeking social emotional support, which is trying to get emotional and social support from others, distancing, issuing cognitive efforts to get away from problems or making a positive hope, Escape avoidance, which is imagining about the situation or take action or avoid unpleasant situations. Individuals do fantasy if the problem goes away and try not to think about problems with sleeping or using excessive alcohol, Self control, which is trying to regulate one's own feelings or actions in relation to solving the problem, Accepting responsibility, that is accepting to run the problem faced temporarily try to think of a way out, and Positive reappraisal, which is to try to make a positive sense of the situation in matters of personality development, sometimes with a religious nature.

Furthermore, coping aspects that focus on the problem are Seeking informational support, which is trying to obtain information from others, such as doctors, psychologists or teachers, Confrontive Coping, concrete problem solving, and Planful problem-solving, analyzing every situation that raises the problem and try to find a solution directly to the problem at hand.

Factors affecting Coping

Lazarus and Folkman (1984) said that individuals from middle-upper socioeconomic groups prefer to use coping patterns that are flexible, logical, and reality. The Coping Strategy process is determined by human resources, one of which is the material resources they have, problem solving skills, positive assessment of the problems faced, someone who has a higher education has more confidence in the Coping Strategy that is problem-centered.

According to Gunarsa (1995), coping is influenced by several factors such as physical condition and heredity, the physical constitution includes the nervous system, muscles, glands and health and disease, social and economic, psychological factors, learning experiences, frustration and conflict self determination, and cultural, cultural and religious factors. The results of Elizabeth, Annette, Kenneth's (2011) research on coping with spiritual stress showed that assessing divorce as a sacred loss or blasphemy when it occurred was predicted to be more symptoms of depression and dysfunctional conflict tactics with former spouses 1 year later.

Coping Strategy Instrument 
The instrument that will be used in this study is the Ways of Coping questionnaire (Lazarus \& Folkman, 1984) which was tested for validity and reliability by Saffrudin (2012) with a value of 0.931 , Handoko (2014) also conducted face validity by providing measurement tools to experts to be assessed. The assessment was carried out by three psychologists tested on 30 people to see their internal consistency and get a Cronbach's alpha value of 0.954. This instrument was also tested by Ratnawati (2015), with a Cronbach alpha value of 0.889 (N: 20). It is known that the instrument is valid with a validity level of $r<0.6$ between 0.305 to 0.665. This questionnaire consists of 52 statement items, some of which reflect stress management strategies that are centered on problems and partly reflect stress management strategies that are centered on emotions. The score for each dimension is obtained by summing the scores of items that represent the dimensions in the Coping Strategy.

*Nursing Department, Universitas Pendidikan Indonesia Andria.pragholapati@upi.edu

\section{REFERENCES}

Ade, M.S., Tjutju, Pragholapati, A., 2016. GAMBARAN KUALITAS HIDUP PADA LANSIA DI BALAI PERLINDUNGAN SOSIAL TRESNA WERDHA CIPARAY BANDUNG TAHUN 2016.

http://ejurnal.stikesbhaktikencana.ac.id/file.php?file=preview_mahasiswa\&id=532\&cd=0b2173 ff6ad6a6fb09c95f6d50001df6\&name=JURNAL\%20SAKINAH\%202016.pdf.

Andria Pragholapati, M.L., 2017. HUBUNGAN MASALAH KESEHATAN JIWA DENGAN STRATEGI KOPING SESEORANG YANG MENGALAMI PERCERAIAN DI KOTA BANDUNG, in: Seminar Nasional Dan Workshop Keperawatan “ Penguatan Profesi Keperawatan Dalam Peningkatan Pelayanan Keperawatan" Continuum of Care Dari Ketergantungan Menuju Kemandirian Hidup Yang Berkualitas. ISBN: 978-602-14422-8-9.

Andria Pragholapati, R., 2018. DEVELOPMENT OF THE INDONESIAN NATIONAL QUALIFICATIONS FRAMEWORK FOR NURSING CURRICULUM, in: International Conference on Education and Regional Development 3rd (ICERD) 2018 “Curriculum for Generation of Discruptive and 4th Industry Revolution Era." p. 44.

Andria Pragholapati, R.M., 2017. HUBUNGAN BULLYING DENGAN KEMAMPUAN SOSIAL PADA REMAJA DI SMK MVP KOTA BANDUNG TAHUN 2017, in: Konferensi Nasional Keperawatan Kesehatan Jiwa XIV Di Kalimantan Selatan Tahun 2017.

Andria Pragholapati, T., 2018. HUBUNGAN PENGGUNAAN SMARTPHONE DENGAN KUALITAS TIDUR PADA REMAJA DI SMK X BANDUNG, in: Konferensi Nasional Keperawatan Kesehatan Jiwa XV Di Hotel Four Point By Sheraton Makassar Sulawesi Selatan. pp. 1-7.

Ardiana, F., Nurlianawati, L., Pragholapati, A., 2016. Gambaran Fungsi Kognitif Pada Lanjut Usia (Lansia) Di Panti Jompo Muhammadiyah dan Yayasan Pondok Lansia Tulus kasih. 


\section{Editorial}

Ariani, A., Pragholapati, A., Pratama, A.S., 2020. Information Communication Technology (ICT) In Midwifery Education: A Review of the Literature, in: The 3rd International Seminar on Global Health (ISGH) "Technology Transformation in Health Care for Better Life" Bandung, West Java, Indonesia. http://repository2.stikesayani.ac.id/index.php/isgh3/article/view/352, pp. 66-69.

Ismawati, Y., Pragholapati, A., 2020. KEJADIAN GASTRITIS DI DESA CINUNUK WILAYAH KERJA PUSKESMAS CINUNUK KABUPATEN BANDUNG.

Ismawati, Y., Sumbara, Pragholapati, A., 2018. HUBUNGAN POLA MAKAN DENGAN KEJADIAN GASTRITIS DI DESA CINUNUK WILAYAH KERJA PUSKESMAS CINUNUK KABUPATEN BANDUNG.

Pragholapati, A., 2020. Self-Efficacy Of Nurses During The Pandemic Covid-19.

Pragholapati, A., 2020. COVID-19 IMPACT ON STUDENTS. osf.io.

Pragholapati, A., 2020. RESILIENSI PADA KONDISI WABAH COVID-19.

Pragholapati, A., 2020. STRES KERJA PERAWAT YANG BEKERJA DI UNIT GAWAT DARURAT (UGD) RUMAH SAKIT AL ISLAM (RSAI) BANDUNG.

Pragholapati, A., 2020. MOTIVASI KERJA PERAWAT DI RUANG RAWAT INAP RSUD MAJALAYA KABUPATEN BANDUNG.

Pragholapati, A., 2020. MENTAL HEALTH IN PANDEMIC COVID-19.

Pragholapati, A., 2020. RESILIENSI PERAWAT YANG BEKERJA DI UNIT GAWAT DARURAT (UGD) RUMAH SAKIT AL ISLAM (RSAI) BANDUNG.

Pragholapati, A., 2020. NEW NORMAL “INDONESIA” AFTER COVID-19 PANDEMIC.

Pragholapati, A., 2019. THE EFFECT OF BRAIN GYM TO THE LEVEL OF DEPRESSION IN GERIATRIC AT BALAI PERLINDUNGAN SOSIAL TRESNA WERDHA CIPARAY BANDUNG. J. Sk. Keperawatan 5, 128-146.

Pragholapati, A., Munawaroh, F., 2020. RESILIENSI PADA LANSIA. J. Surya Muda 2, 1-8.

Pragholapati, A., Ulfitri, W., 2019. Gambaran Mekanisme Coping pada Mahasiswa Program Studi Sarjana Keperawatan Tingkat IV yang Sedang Menghadapi Tugas Akhir di Sekolah Tinggi Ilmu Kesehatan X Bandung. Humanit. J. Psikol. 3, 115-126.

Prasetyo M, D., Nurlianawati, L., Pragholapati, A., 2017. GAMBARAN TINGKAT KECEMASAN PADA PASIEN PRE OPERASI FIBROADENOMA MAMMAE DI RUANG GUNTUR RUMAH SAKIT TK II DUSTIRA CIMAHI TAHUN 2017.

http://ejurnal.stikesbhaktikencana.ac.id/mahasiswa.php?detail=mahasiswa\&id .... 
Rahmawati, S.D., Mulyati, T., Pragholapati, A., 2015. HUBUNGAN BODY IMAGE DENGAN POLA DIET PADA REMAJA PUTRI DI SMAN 24 BANDUNG TAHUN 2015.

http://ejurnal.stikesbhaktikencana.ac.id/file.php?file=preview_mahasiswa\&id ....

Rosmala, I., Jundiah, S., Pragholapati, A., 2017. TINGKAT KECEMASAN PADA KELUARGA PASIEN DI RUANG ICU RSUD MAJALAYA KABUPATEN BANDUNG TAHUN 2017. http://ejurnal.stikesbhaktikencana.ac.id/file.php?file=preview_mahasiswa\&id=517\&cd=0b2173 ff6ad6a6fb09c95f6d50001df6\&name=Jurnal\%20Imas\%20Rosmala\%202017.pdf.

Septriani, D., Sari, Y.R., Pragholapati, A., 2019. The Relationship of Social Support With the Anxiety Level of Parents of Children with Thalassemia of Pre-School Age that Works in the Activities of Blood Transfusion in Hospital " $X$ " Bandung, in: The 2nd Bandung International Conference on Collaborative Health Research Research. Prama Grand Preanger Hotel Bandung, West Java, Indonesia 7th - 8th of October 2019. p. 12.

Virgona, A., Pragholapati, A., 2019. Enhancing Critical Thinking Skills in Nursing Higher Education in Preparation for the Industrial Revolution 4.0: Literature Review, in: The 3rd International Seminar on Global Health (ISGH) "Technology Transformation in Health Care for Better Life" Bandung, West Java, Indonesia. 